\title{
TINJAUAN TEOLOGIS PAEDAGOGIS KORELASI PENDIDIKAN AGAMA KRISTEN (PAK) GEREJA DAN KELUARGA DAN RELEVANSINYA BAGI PELAYANAN GEREJA MASA KINI
}

Trisno Kurniadi

\author{
trisnokurniadi@sttab.ac.id
}

\begin{abstract}
There are things that are relevant but neglected, and there are also things that are closely related but are forgotten in family life and church service. That is the importance of Christian Religious Education in the context of family and church services today. But the correlation between Christian Religious Education and family would not be realized if there were no educators who understood the nature of Christian Religious education. Therefore through this paper, the author reviews theologically the pedagogical education of the Christian Religion (PAK) of the Church and family and their relevance to the service of the church today.
\end{abstract}

Keywords: Overview, Theological, Paedagogis, Christian Religious Education, Relevance, Today's Church.

Abstrak: $\quad$ Ada hal yang relevan namun terabaikan, dan juga ada hal yang saling terkait erat namun dilupakan dalam kehidupan keluarga dan pelayanan digereja. Yaitu pentingnya Pendidikan Agama Kristen dalam konteks keluarga dan pelayanan gereja masa kini. Namun korelasi antara Pendidikan Agama Kristen dan keluarga tidak akan terwujud jika tidak adanya pendidik yang memahami hakikat pendidikan Agama Kristen. Oleh karena itu melalui tulisan ini, penulis meninjau secara teologis paedagogis pendidikan Agama Kristen (PAK)Gereja dan keluarga dan relevansinya bagi pelayanan gereja masa kini.

Kata Kunci: Tinjauan, Teologis, Paedagogis, Pendidikan Agama Kristen, Relevansi, Gereja Masa Kini.

\section{PENDAHULUAN}

Secara sepintas menurut B.S. Sidjabat, Pendidikan Kristen dapat saja diartikan sebagai “ Pendidikan yang Kristen.” Artinya, pendidikan yang bercorak atau berdasarkan dan berorientasi Kristiani. ${ }^{1}$ Menurut L. Hulmes, bahwa pendidikan Kristen merupakan segala macam pendidikan dasar yang dapat disebut Kristen, baik pendidikan umum yang disampaikan dari pandangan Kristen maupun pendidikan khusus untuk orang mengenai segala hal keristenan. ${ }^{2}$

Dari pengertian yang dipaparkan di atas, ditinjau dari dasar pengajaran, oleh karena Pendidikan Kristen adalah pendidikan yang berorientasi dan bercorak Kristen, maka Yesus dan Alkitab menjadi dasar dalam pendidikan. Hal ini juga dijelaskan oleh Sidjabat :

\footnotetext{
${ }^{1}$ BS. Sidjabat, Strategi Pendidikan Kristen, (Yogyakarta: Yayasan Andi, 1994), 10

${ }^{2}$ L. Hulmes, Arah Pendidikan Kristen ( Batu: YPPII, 1982), 24
} 
"Bahwa suatu proses pendidikan disebut Kristen karena ia memiliki dasar Alkitab dan Theologis". ${ }^{3}$ Lebih lanjut Verkuyl mengatakan bagi iman Kristen, norma pendidikan itu tidak ada lain kecuali norma Kurios Yakni Injil Yesus Kristus dan Taurat-Nya, janji-janjiNya dan tuntutan-tuntutan Tuhan."4

Adapun Tujuan dari Pendidikan Kristen dinyatakan jelas dalam Perjanjian Lama maupun dalam Perjanjian Baru (bnd. Ul 6:6-9; 11:18-19; Maz 78; Mat 28:19-20; Luk 24: 13-35, dll). John $\mathrm{T}$ Sisemore berpendapat bahwa tujuan pendidikan Kristen adalah terjadinya progress toward maturity, yaitu untuk mencapai kematangan rohani, dan hal ini didasarkan pada Efesus 4:13. ${ }^{5}$ L. Hulmes ia lebih menyoroti tujuan Pendidikan Kristen dari sisi perubahan bagi terdidik, yaitu meliputi perubahan dalam kehidupan terdidik yang berkaitan dengan sikap dan tingkah laku yang berakibat baik bagi orang lain yaitu kehidupan orang-orang disekelilingnya diberkati dan menjadi murid Kristus. Dengan mengungkapkan sebagai berikut:

Inilah klimaks dan tujuan dari Pendidikan Kristen orang yang dibaptiskan sebagai murid-murid Kristus, sehingga menjadi saksi Kristus yang baik karena kebenaran Kristus dihayati dalam sikapnya, tingkah lakunya, perbuatannya dan kata-katanya oleh Roh Kudus maka orang-orang disekelilingnya akan tertarik dan menjadi murid Kristus. ${ }^{6}$

Hal ini searah dengan Misi filosofis Pendidikan Agama Kristen, yaitu: 1). Mempertemukan pribadi orang berdosa kepada Kristus. 2) Mengubah karakter orang percaya, dan 3). Membawa orang percaya untuk menjadi saksi Kristus. Yang menjadi pertanyaan siapa yang bertugas dan bertanggung jawab terhadap Pendidikan Agama Kristen (PAK) di Gereja dan Keluarga? Dan siapa penerima PAK baik di Gereja maupun di Keluarga?

Sulaiman menjawab pertanyaan itu serta memberi contoh-contoh dalam Alkitab dengan menjelaskan sebagai berikut:

Dalam Perjanjian Lama yang bertanggung jawab adalah para Imam, Nabi dan juga orang tua (bnd. Ul 6). Dalam Perjanjian baru yang bertanggung jawab adalah Yesus, para Rasul, Guru Agama, Penginjil dan orang tua. Dalam Gereja dan Jemaat yang bertanggung jawab adalah Majelis Gereja melalui berbagai komisi-komisi ( Anak, Remaja, Pemuda, Dewasa dan Tua $)^{7}$

Jadi jelas dari penjelasan C. Sulaiman yang bertugas dan bertanggung jawab serta menerima PAK adalah Gereja dalam pengertian jemaat dan Keluarga. Oleh karena Gereja

\footnotetext{
${ }^{3}$ B. Sidjabat. Op. Cit

${ }^{4}$ J. Verkuyl. Aku Percaya ( Jakarta: BPK Gunung Mulia, 1984)

${ }^{5}$ John T. Sisemore, Vital Principle In Religius Education ( Nasvile: Broodman Press, 1966), 19

${ }^{6}$ L. Hulmes, Op.Cit

${ }^{7}$ C. Sulaiman, Lokakarya PAK dan Statistik PAK ( Sukabumi, Dirjen Bimas Kristen, 1977), 18-19
} 
dan Keluarga merupakan wadah bagi anak-anak, Remaja dan Pemuda, orang dewasa dan orang tua. Robert Zacharias dalam R. Boelke mengatakan:

PAK mencakup segala sesuatu yang menjadi tugas pendidikan gerejawi, termasuk didalamnya PWG. PAK mencakup seluruh kegiatan Gereja dalam mendidik anggota dan calon anggota untuk hidup dalam kehidupan Kristen baik yang diselenggarakan di dalam Gereja maupun yang diselenggarakan dalam sekolah-sekolah dan dalam keluarga. ${ }^{8}$

Permasalahannya, berdasarkan pengalaman dan pengamatan penulis, selama kurang lebih dua puluh tiga tahun menggembalakan dan dalam pergaulan oikoumene serta pengamatan terhadap gereja-gereja, Gereja dan Keluarga pada masa kini cenderung kehilangan fungsi dalam melaksanakan Pendidikan Agama Kristen. Oleh sebab itu melalui tulisan ini berusaha menggungah kembali kesadaran gereja Tuhan dan keluarga untuk kembali kepada fungsinya dan tanggung jawabnya dalam Pendidikan Agama Kristen.

\section{KORELASI PENDIDIKAN AGAMA KRISTEN (PAK) GEREJA DAN KELUARGA Korelasi Teologis}

\section{Mandat Mengajar}

Dalam Kamus Besar Bahasa Indonesia, mandat memiliki beberapa pengertian diantaranya:

1). Perintah atau arahan yang diberikan oleh banyak orang (rakyat, perkumpulan dsb) kepada seseorang (beberapa orang) untuk dilaksanakan sesuai dengan kehendak orang banyak itu. 2). Kekuasaan untuk melakukan kewenangan kekuasaan dari suatu badan atau organ kekuasaan atas nama badan atau organ kekuasaan tersebut. ${ }^{9}$

Dalam Oxford Advanced Learner's Dictionary dijelaskan: Mandat 1 (of a Countary or state) placed under the rule of another country; mandate territories 2 . Required by law; a mandate curriculum, 3. Having a mandate to do sth: a mandate governent ${ }^{10}$. Dari kedua pengertian tersebut diatas, mandat didalamnya ada unsur perintah, kekuasaan untuk melakukan perintah dari orang/badan yang memberikan mandat.

Secara teologis gereja maupun keluarga mempunyai mandat untuk mengajar. Oleh karena perintah mengajar dalam Matius 28:19-20 tidak hanya diberikan kepada Gereja tetapi juga kepada keluarga. Tuhan sebagai pengajar Agung telah memberikan amanat mengajar kepada Gereja. Gereja mempunyai tanggung jawab terhadap pendidikan atau

\footnotetext{
${ }^{8}$ Robert R, Boehlke, Sejarah Perkembangan Pemikiran dan Praktik Pendidikan Agama Kristen (Jakarta: BPK Gunung Mulia, 1997), 812

${ }^{9}$ Hasan Alwi, Kamus Besar Bahasan Indonesia (Jakarta: Pusat Basaha Departemen Pendidikan Nasional, 2001), 709

${ }^{10}$ As Horby, Oxford Advanced Leaner's (Oxford: University Press, 2000),779
} 
pembinaan. Karena itu pergilah, jadikalah semua bangsa murid-Ku dan baptislah mereka dalam nama Bapa dan Anak dan Roh Kudus, dan ajarkanlah mereka melakukan segala sesuatu yang telah kuperintahkan kepadmu, dan ketahuilah Aku menyertai kamu senantiasa sampai kepada akhir zaman (Mat 28:19-20). Dalam ayat ini mempunyai empat kata kerja: 1). Pergilah, 2). Jadikanlah, 3). Baptiskanlah dan 4). Ajarlah. Menurut Humes dalam bahasa Yunani ayat 19 ini hanya mempunyai satu kata kerja yaitu Matheteosate yang berarti "Jadikanlah...Murid" cara untuk menjadikan murid "Baptislah..., yang merupakan peneginjilian yang berhasil dan ajarlah... yang merupakan proses lanjutan dalam membuat orag menjadi murid Kristus dewasa. Dalam ayat ini ada unsur Pendidikan Kristen yang dituntut Tuhan Yesus adalah pendidikan yang sungguh mencapai tujuan akhir" ajarlah mereka melakukan segala sesuatu yang telah kuperintahkan kepadamu."11

Dalam amanat Agung ini sebenarnya bukan hanya berbicara tentang amanat untuk memberitakan Injil tetapi juga amanat pendidikan untuk mengajar. Tugas ini harus dilakukan oleh pengikut-pengikut Kristus baik Gereja maupun keluarga sebagaimana juga dikatakan oleh JH Bavink "Bahwa perintah itu tidak saja disampaikan kepada muridmurid-Nya tetapi juga kepada Gereja dari seluruh abad."12

\section{Korelasi Paedagodis}

Secara paedagogis PAK Gereja dan PAK Keluarga memiliki kesamaan dalam beberapa hal diantaranya: pendidik, metode, kurikulum, tujuan dan evaluasi. Namun dalam pembahasan padan tinjauan paedogogis PAK Gereja dan Keluarga yang dibahas yakni sekitar pelaksana Proses Belajar Mengajar yang terdiri dari: pendidik, anak didik dan isi/materi.

\section{Pendidik/Pengajar}

\section{Persyaratan bagi seorang pendidik}

Dari segi pribadi guru, baik guru PAK Gereja dan PAK Keluarga memiliki persyaratan yang sama.

\section{Menurut EG Homrighausen}

Syarat-syarat guru Pendidikan Agama Kristen adalah: 1). Seorang guru harus memmpunyai pengalaman rohani. Perlu sekali ia sendiri mengenal Tuhan Yesus. Batinnya harus dijamah dan diterangi oleh Roh Kudus. Inilah syarat yang terutama janganlah ia dipermainkan.2). seorang guru harus mempunyai hasrat sejati untuk menyampaikan Injil kepada sesamanya manusia. Harus ada dorongan kuat untuk mengantar orang lain kepada Yesus Kristus. 3). Seorang guru harus mempunyai pengetahuan yang cukup tentang isi

\footnotetext{
${ }^{11}$ Hulmes, Op.Cit,39-40

12 JH. Bavink, Op.Cit, 658
} 
iman Kristen. Ia harus mengenal Alkitab dengan baik. Untuk itu ia sendiri perlu dididik dan dilatih sebelum mengajar orag lain. 4). Seorang guru perlu mengetahui bagaimana iman bertumbuh dalam batin manusia dan bagaimana iman itu berkembang dalam seluruh hidup orang percaya itu. Ini berarti si guru banyak sedikit harus mempelajari ilmu jiwa yang berhubungan dengan soal-soal agama. 5). Seorang guru haris menunjukkan kesetiaan yang sungguh kepada gerejanya. Ia sendiri harus rajin mengambil bagian dalam kebaktian dan pekerjaan gereja pada umumnya dan jangan hanya menaruh minat terhadap tugasnya sendiri. 6).seorang guru harus mempunyai pribadi yang jujur dan tinggi mutunya. ${ }^{13}$

\section{Menurut BS. Sidjabat}

Ada tiga hal penting yang perlu dimiliki seorang guru Pendidikan Agama Kristen yaitu Pengalaman rohani, pengetahuan dan karunia. Pengalaman Rohani, Pertama, soal pandangannya terhadap Alkitab. Alkitab adalah Firman Allah yang tidak mungkin keliru dan berotoritas (II Tim 3:16, 2 Ptr 1:19-20). Seorang guru PAK harus memiliki pandangan Alkitab adalah firman Allah. Kedua. Seorang guru PAK harus sudah lahir baru, oleh pembaharuan roh Kudus sebagai hasil percaya dan menerima Yesus sebagai Juruselamat penebus dosa pribadinya (Ef 1:13-14). Ketiga, Keyakinan bahwa Yesuslah jalan kebenaran dan hidup (Yoh 14:6) Dialah yang menjadi berita dalam pengajarannya (Kol 1:28-30). Pengetahuan, pertama, guru perlu memiliki pengetahuan Alkitab dalam dalam. Mengetahui Alkitab, dalam hal ini termasuk juga memahami dan trampil menafsirkan Alkitab dengan benar dan tepat. Kedua, guru perlu memiliki pengetahuan yang luas dan aktual dalam bidang-bidang lain, walaupun ia tidak mungkin menguasainya sebagai seorang ahli. Ketiga, memiliki keterampilan dalam proses belajar mengajar. Keempat, guru perlu terampil mengitegrasikan kebenaran Alkitab dengann kebenaran rii disiplin ilmu lain untuk pengajaran yang benar. Karunia Khusus, mengajar adalah karunia yag disiapkan oleh Tuhan (Efesus 4:11-13; Roma 12:6-8). ${ }^{14}$

3. Menurut Frank E. Gabel dalam Kannet O Gangel ada enam kriteria seorang guru PAK

1). Karena guru adalah seorang yang menyampaikan kebenaran, ia harus merupakan orang Kristen yang harus terang dan berani. Pendidikan Kristen memerlukan guru-guru Kristen; kalau tidak maka yang dihasilkan bukan Pendidikan Kristen. Kalau tidak ada yang dihasilkan bukan pendidikan Kristen. 2). Setiap guru harus mengenal Alkitab, karena Firman Allah relevan sengan semua pengajaran, prinsip ini harus berlaku

\footnotetext{
${ }^{13}$ EG. Horigahausen ${ }_{3}$ Pendidikan Agama Kristen (Jakarta: BPK Gunung Mulia, 1999),165-167

${ }^{14}$ BS. Sidjabat, Pengantar Ketinjauan Historis Filosofis (Bandung: IAT, 1987), 71-74
} 
untuk para guru semua pelajaran tersebut dan juga guru-guru pelajaran Alkitab; 3). Guru Kristen dalam setiap aspek kehidupan dankerjanya, dalam seluruh keberadaaannya, harus melakukan kebenaran, termasuk kejujuran secara tetap; 4). Guru itu harus mencari mutu terbaik. Ini adalah pencarian mutu terbaik bidang intelktual untuk kemuliaan Allah. Dan seorang Guru Kristen tidak boleh puas kalau dia belum unggul dalam bidang ini. Guru itu harus berjuang untuk memenuhi berbagai persyaratan dari dunia yang banyak permintaannya, dengan menghindari dosa yang berupa keadaan sedang-sedang saja; 5). Guru Kristen harus benar-benar mengasihi murid-muridnya, mengusahakan yang terbaik bagi mereka, sekalipun kadang-kadang caranya mungkin sulit. Dia bukan hanya harus mengasihi mereka. "menyukai” berdasarkan kehendak Allah sangat diperlukan untuk bisa mengajar secara efektif; 6). Yang terakhir Guru Kristen harus patuh sepenuhnya kepada sang guru agung. "Inilah anak-Ku uang Kupilih, dengarkanlah Dia." (Luk 9:35). Setiap guru harus mendengarkan Tuhan berkenaan dengan Pelajaran yang ia berikan dan ia jangan pernah berfikir bahwa ia tidak perlu diajar oleh-Nya ${ }^{15}$

Dari penjelasan-penjelasan yang disampaikan oleh beberapa ahli diatas maka dapat dikemukakan bahwa syarat utama bagi seorang guru Pendidikan Agama Kristen adalah sudah lahir baru, bertobat menerima Tuhan Yesus sebagai Juru selamat pribadi. Guru PAK Gereja maupun PAK Keluarga perlu memiliki persyaratan ini dan Gereja perlu merekrut, mempersiapkan jemaat menjadi pribadi yang memiliki kriteria seperti diatas. Sehingga mereka dapat berperan menjadi guru-guru PAK baik dilingkungan gereja maupun keluarga.

\section{a. Tenaga Pendidik/Pengajar}

1. Pendeta/gembala

Pendeta/Gembala merupakan orang penting dalam program Pendidikan Agama Kristen. J.L. Ch. Abineno dalam bukunya menjelaskan tentang tugas/Fungsi seorang pendeta pada umumnya adalah:

1) Melayani pemberitaan Firman Allah dan sakramen.

2) Memimpin Katekisasi (Pengajaran Agama)

3) Meneguhkan anggota Sidi

4) Mentahbiskan pelayan-pelayan khusus dalam jabatan mereka

5) Memberkati dan meneguhkan nikah

6) Memimpin penguburan orang mati

7) Mengembalakan anggota-anggota jemaat

8) Bersama-sama dengan penatua-penatua memimpin jemaat dan menjalankan disiplin gereja

\footnotetext{
${ }^{15}$ Kenneth O Gangel, Membina Pemimpin Pendidikan Kristen (Malang: Gandum Mas, 1998), 44
} 
9) Bersama-sama dengan diaken-diaken melakukan pelayanan diakonia. ${ }^{16}$

Dari apa yang dijelaskan oleh Abineno tentang fungsi/tugas pendeta atau gembala, dapat dikemukkan bahwa ada dua tugas yang berkaitan dengan paedogogis yaitu pemberitaan Firman Allah dan Katekisasi. Elli Tanya juga menjelaskan akan fungsi/tugas pendeta sebagai pendidik dengan mengatakan Pendeta adalah seorang pengajar khusus dimana ia secara langsung mengajar, misalnya:

- Ia mengajar kelas Katekisasi, yaitu kelas bimbingan untuk pemuda atau dewasa yang ingin mengakuu Yesus sebagai Juruselamat dan Tuhan mereka dan ingin memahami iman Kristen.

- Ia mengajar teologi untuk mengajar warga jemaat yang diselenggarakan oleh jemaat atau dengan kerjasama sekolah seminari. Warga jemaat memerlukan pengetahuan teologis, pengetahuan Alkitab, keterampilan mengajar, perlawatan dana cara-cara khotbah dan sebagainya untuk mendalami iman Kristen.

- Ia berkhotbah di mimbar gereja. Wadah ini penting untuk membimbing dan mengajar jemaat, demi pertumbuhan rohani mereka. ${ }^{17}$

2. Penatua

Dalam Titus 1:5-7 Penatua disebut juga penilik jemaat dan syarat-syarat moral bagi penilik jemaat disajikan dalam I Tim 3:1-7; Titus 1:5-9. Kewajiban-kewajiban Penatua adalah sebagai berikut: memimpin (I Tim 5:17), mengatur rumah Allah (Titus 1:7), cakap mengajar (I Tim 3:2), berkhotbah dan mengajar (I Tim 5:17).

3. Orang Tua

Orang tua baik itu ayah sebagai kepala keluarga maupun ibu sangat berperan sebagai pendidik/pengajar Pendidikan Agama Kristen. Pada keduanya itu dapat dilihat dalam Amsal 22:6; II Tim 1:5; 3: 14-15. Dimana dalam ayat-ayat ini dijelaskan bahwa orang tua harus mengabdikan diri mereka untuk memberi didikan kepada anak-anak mereka.

\section{b. Perlengkapan Seorang Pendidik}

1) Mengenal Alkitab

Materi pengajaran Pendidikan Agama Kristen adalah dari Allah sendiri dan bersumber dari Alkitab. Oleh sebab itu, perlunya pendidik untuk membaca Firman Tuhan secara teratur sehingga pengenalan akan Allah dan sabda-Nya/Alkitab akan berkembang. Ruth Laufer mengatakan:

Seorang ahli telah berkata: "Untuk mengajar Alkitab kepada anak selama satu jam, guru harus hidup sesuai dengan Firman Allah selama satu minggu." Tidak hanya apa yang dikatakan kepada anak akan berkesan, keberadaan guru juga akan berkesan secara dalam. Umpamanya jikalau guru memberikan pengajaran mengenai kepanjang sabaran Tuhan,

\footnotetext{
${ }^{16}$ JL. Ch. Abineno, Jemaat (Jakarta: BPK Gunung Mulia, 1965), 123

${ }^{17}$ Eli Tanya, Gereja dan Pendidikan Agama Kristen (Cipanas: STT Cipanas, 1999), 98-99
} 
padahal ia kurang sabar terhadap anak, keadaannya bberlainan dengan kata-katanya. ${ }^{18}$

2) Mengenal Anak Didik

Dengan mengenal anak didik kita akan dapat menyampaikan pengajaran menurut pengertian dan daya tangkap mereka. dan kita dapat mengenal anak didik melalui membaca buku, bergaul dengan mereka, melalui perkunjungan dan sebagainya. Peserta didik sebagai penerima Pendidikan Agama Kristen sebagaimana dijelaskan dalam Bab pendahuluan bahwa jangkauan PAK adalah semua umur, anak-anak, remaja, Pemuda maupun dewasa baik itu sebagai anggota jemaat maupun anggota keluarga.

Peserta didik adalah bagian yang paling penting dalam proses belajar mengajar. Bagaimana proses belajar mengajar bisa berjalan kalau tidak ada peserta didikya. Bagian penting lain adalah dengan adanya peserta didik akan mendorong pendidik untuk mempersiapkan diri dalam proses belajar mengajar bak itu dalam belajar mengenai peserta didik, belajar/mengenal cara ,mengajar dan sebagainya. Sebagaimana juga diungkapkan oleh Tertius Sudiono:

Murid adalah bagiann yang paling penting dalam proses belajar mengajar. Meskipun PAK mengharuskan kita terus berpusat kepada Firman Allah, murid kitapun harus tetap juga didalam pusat itu. Firman Allah diajarkan kepada mereka agar mereka mampu memantulkan dirinya seperti Kristus. Murid-murid itu harus tahu bahwa mereka adalah orang-orang yang sedang berkembang... setiap tahapan pertumbuhan mempunyai cirinya sendiri dalam hal perkembangan serta wataknya. Akan tetapi setiap individu tentu saja akan menampilkan pola perkembangan yang berbeda dengan orangorang lain yang membuat dia unik bagi dirinya. Salah satu dari maksud memahami individu seorang murid adalah memenuhi kebutuhannya sebagai manusia seutuhnya. ${ }^{19}$

3) Mengenal Cara Mengajar

Dengan mengenal cara mengajar, maka proses belajar mengajar akan bisa berjalan dengan baik serta tujuan mengajar bisa tercapai dengan maksimal. Menurut H. Budiyana, isi/materi yang terdapat dalam kurikulum mengaku kepada tujuan yang hendak dicapai baikk oleh guru maupun siswa. Secara khusus menggambarkan bentuk perubahan tingkah laku yang diharapkan dalam pencapaian tujuan oleh siswa melalui roses belajar mengajar.

Tujuan dari pengajaran PAK adalah mengarah pada satu perubahan dalam bidang knowlge, efektif dan psikomotorik yang searah dengan misi filosofis PAK yaitu, membawa orang berdosa kepada Kristus, mengubah karakter dan menolong orang untuk

\footnotetext{
${ }^{18}$ Ruth Laufer, Pedoman Pelayanan Anak (Batu: Dep.Lit YPPII, 1997), 16

${ }^{19}$ Tertius Soediono, Pembimbing PAK (diktatkuliah) (Yagyakarta: Fakultas Agama Kristen
} UKRIM, 1994),52 
menjadi saksi Kristus. Maka materi harus sesuai dengan kurikulum. Menurut Robert K. Bower dalam Eli Tanya, sekurang-kurangnya isi kurikulumPAK meringkas pokok-pokok yang komprehensif yaitu:

1. Iman Kristen meliputi hakekat Allah, Roh Kudus, Yesus Kristus, manusia, gereja, Alkitab, dan pengetahuan tentang filsafat-filsafat dunia, juga tafsiran Kristen tentang alama semesta.

2. Alkitab Firman Allah. Umat Kristiani harus mengerti tentang hakikat Alkitab itu. Tentang sejarah terjadinya, pemakaiannya pada berbagai kesempatan, metodemetode studi PB dan bagaimana mengajarnya.

3. Kehidupan Kristen, meliputi pergaulan, pekerjaan, menjadi orang tua yang bertanggung jawab dan sebagainya.

4. Masalah sosial, meliputi asas-asas Kristen dalam pergaulan dengan masyarakat dsb.

5. Hubungan dengan dunia, meliputi misi keseluruh dunia. ${ }^{20}$

\section{Korelasi Dalam Kesamaan Tujuan PAK}

Baik Pendidikan Agama Kristen (PAK) Gereja maupun Pendidikan Agama Kristen (PAK) Keluarga memiliki kesamaan dalam Tujuan . Adapun tujuan dari pada PAK Gereja dan Keluarga adalah

\section{Mempertemukan pribadi orang berdosa kepada Kristus}

Pembahasan pada bagian ini berkaitan dengan bagaimana seseorang dapat dilahirkan kembali sehingga mereka dapat bertemu dengan Kristus? Hal-hal yang perlu dipahami agar dapat dilahirkan kembali adalah: Pertama, sadar akan dosa (Roma 3:23; Roma 6:23). Kedua, sadar akan kasih Allah, menyadari kasih Allah behitu besar sehingga Yesus memberikan hidup-Nya kepada orang berdosa, mati diatas kayu salib untuk menebus dosa umat manusia (Mat 1:21; Yoh 3:16). Ketiga, mengaku dosa (I Yoh 1:7-9). Keempat, menerima Tuhan Yesus sebagai Tuhan dan Juruselamat pribadi. Hal ini juga dijelaskan oleh Luis Palau "Bagaimana seseorang menjadi Kristen, dalam pertumbuhan imannya, orang Kristen dimulai sejak kelahiran baru.” Hal-hal yang perlu diperhatikan menurut Louis:

Langkah Pertama, mengaku bahwa dosa saudara menjauhkan saudara dari Allah. Alkitab mengatakan bahwa tidak ada perbedaan diantara manusia sebah kita sekalian telah berbuat dosa dann telah kehilangan kemuliaan Allah (Roma 3:9-23). Kita dapat mengingkari akan keberadaan kita sendiri dan kebenaran tidak ada dalam kita... jika kita berkata bahwa kita tidak berbuat dosa, maka kita membuat Dia menjadi pendusta dan firman-Nya tidak ada dalam kita II Yoh 1:8-10). Langkah Kedua, adalah percaya bahwa Yesus Kristus telah mati di kayu salib untuk membawa kita kembali kepada Allah.

\footnotetext{
${ }^{20}$ Eli Tanya, Gereja dan PAK (Cipanas: STT Cipanas, 1999),32
} 
Langkah Ketiga, adalah menerima Tuhan Yesus Kristus sebagai Juruselamat dengan jalan membuat satu keputusan pribadi. ${ }^{21}$

\section{Mengubah Karakter}

Perubahan karakter yang diharapkan pada bagian ini adalah bagaimana setiap orang yang percaya kepada Yesus mengalami perubahan terus menerus, sehingga orang yang percaya kepada Kristus bukan hanya sekedar memiliki identitas sebagai orang Kristen tetapi diperbaharui sampai ada tindakan nyata. Oleh sebab itu untuk mewujudkannya, H. Budiyana mengatakan: Orang percaya harus mengerti hal-hal: Manusia baru dalam Kristus, manusia yang menghasilkan buah-buah Roh (gal 5:22-24) dan manusia meletakkan dasar Kristus dalam hidupnya dan membangun terus kehidupan sesuai dengan karunia dan talenta.

\section{Membawa Seseorang Untuk Menjadi Saksi Kristus}

Dalam bagian ini perlunya penyadaran kepada terdidik bahwa kita harus memberitakan Injil. Untuk itu perlunya terdidik memahami pokok-pokok pembahasan sekitar penginjilan. Luis Palau memberikan dua alasan mengapa harus memberitakan Injil?

Pertama, Ia menyuruh kita. Dalam perkataan Yesus, "KepadaKu telah diberikan segala kuasa di sorga dan di bumi, karena itu pergilah, jadikanlah semua bangsa murid-Ku dan babtislah mereka dalam nama Bapa, Anak dan Roh Kudus, dan ajarlah mereka melakukan segala sesuatu yang telah Kuperintahkan kepadamu, dan ketahuilah Aku menyertai kamu senantiasa sampai pada akhir zaman (Mat 28:19-20).

Kedua, adalah kasih dan belas kasihan bagi sesama kita manusia. Kita dibatasi oleh waktu dan ruang, jadi kita tidak bisa melihat sebelumnya siapa yang akan menerima juruselamat. Sebab kita telah menerima begitu banyak, kitapun seharusnya memberitahu orang lain apa kerugian mereka hidup tanpa Kristus. Kita tidak akan selalu mengenal orang secara pribadi, tetapi kita mengenal Tuhan dan kita bisa memberitahu orang lain mengenai Dia. ${ }^{22}$

\section{RELEVANSINYA BAGI PELAYANAN GEREJA MASA KINI Gereja dan Keluarga Saling Membutuhkan}

\section{Keluarga sebagai gereja Miniatur}

Keluarga dikatakan sebagai gereja miniatur oleh karena: 1). Keluarga merupakan persekutuan orang-orang percaya yang telah ditebus. Sebagaimana salah satu definisi gereja dikatakan : jika kata "gereja"berhubungan dengan sebuah kelompok, ini adalah 
kelompok orang-orang yang sangat terbatas sekali, yaitu jemaat-jemaat yang berhimpun dii rumah-rumah. Sifat dasar orang-orang ini (paling tidakk pada zaman PB) adalah mereka mengakui telah menerima Kristus sebagai Juruselamat. Dalam beberapa contoh, mereka hanya mengakui namun tidak memiliki keselamatan. Telah dikaitan dengan jemaat-jemaat lokal (I Yoh 2:19; Why 3:20). Tapi untuk menjadi jemaat-jemaat Kristen, orang-orang harus membuat sebuah pengakuan sebagai orang Kristen (bnd. Charles Ryrie, 184-185). Dalam lingkup keluarga, peranan gereja dalam pertumbuhan rohani secara tidak langsung diterapkan dalam kehidupan anggota keluarga sehari-hari, oleh karena dalam lingkungan keluarga anggota keluarga bisa belajar bagaimana hidu dalam persekutuan dengan sesama orang beriman; belajar saling membagi pengalaman dan saling memotivasi tolong menolong antara sesama orang Kristen; belajar saling bertanggung jawab dan membagi hikmat, belajar bekerja sama untuk saling melayani antara satu dengan yang lain.

Sebagaimana diungkapkan oleh Ricard Lovelace baghwa gereja memainkan empat peranan penting dalam pertumbuhan rohani seorang Kristen.

Pertama, ibadah kita dirancang oleh Allah untuk bertumbuh dalam persekutuan dengan sesama orang beriman. Tuhan mengumpulkan kita seperti batu-batu yang hidup untuk membangun suatu rumah yang didalamnya Ia berkenan untuk tinggal (I Ptr 2:5) dalam kitab Efesus, Paulus mengatakan bahwa kita adalah anggota keluarga Allah dan menjadi suatu rumah kudus. Waktu kita berkumpul bersama, kita menjadi tempat kediaman Allah di dalam Roh (Ef 2:19-22). Ketika kita berkumpul dengan sesama orang Kristen untuk beribadah, cakrawala kita diperluas dan kita semakin dikuatkan.

Kedua, pengasuhan, jemaat memberikan makan dan vitamin rohani yang hanya dapat diperoleh dalam keloompok yang lebih besar. Gereja adalah stasiun pusat tempat karunia dibagikan, penghiburan diberikan kepada yang lain, dan nasihat disampaikan. Kita bukan penyelam laut dalam secara rohani yang masing-masing memakai tabung oksigen sendiri dihubungkan dengan Allah. Allah telah merancang kita untuk saling membagi pengalaman dan saling memberi dorongan antara sesama orang Kristen.

Ketiga, nasihat, kalau kita sendirian mudah jalan menyimpang. Di dalam kelompok yang lebih besar kita dapat saling bertanggung jawab dan saling membagi hikmat kita. Dalam Amsal 27:17 kita baca "besi menajamkan besi".

Keempat. Pelayanan, dalam jemaat kita dapat menyatukan dana dan kemampuan kita untuk menjangkau orang lain datang kepada Kristus. Kita dapat berhubungan dengan orang Kristen lain yang sama melayani. ${ }^{23}$

Berkenaan dengan keluarga sebagai miniature gereja Edward Hays dalam pengantar bukunya yang berjudul Prayer fot the domestic Church mengatakan: Altar 
pertama yang dipuji oleh orang-orang primitof adalah tungku perapian yang menyalanyala ditengah rumah tangga. Altar berikutnya adalah meja makan keluarga dimana makanan dirayakan dan peristiwa-peristiwa besar dalam sejarah keluraga diperingati. Pendeta pria dan Pendeta perempuan pada upacara pertama adalah pada bapak dan ibu keluarga tersebut. Lebih lanjut Morjorie menjelaskan, tradisi dan kebiasaan Yahudi masih menyatakan pemahaman kuno mengenai rumah sebagai pusat peribadatan. Kepercayaan Yahudi dimaknai oleh suatu "Spiritualisasi meja" dimana perayaan-perayaan penting di hari-hari suci diperingati disekitar altar yaitu meja keluarga. ${ }^{24}$

a. Keluarga sebagai ujung tombak Misi Gereja

Allah dalan Tuhan Yesus Kristus telah memilih, menyelamatkan dan mengutus gereja-Nya sebagai duta kerajaan-Nya dengan tugas sebagai berikut: Pelayanan Koinonia (pelayanan pembinaan persekutuan), pelayanan Marturia (Pelayanan Pemberitaan Injil) dan pelayanan Diakonia (Pelayanan Kasih da Sosial). Melihat tugas dan panggilan gereja (Koinonia, Marthuria, Diakonia) dan yang menjadi objek dan subjek adalah Jemaat maupun masyarakat, maka keluarga-keluarga memegang peranan penting dalam merealisasikan tugas dan tanggung jawab tersebut. Alasannya:

Pertama, Allah telah mengarunikan karunia-karunia dalam keluarga-keluarga yang adalah warga jemaat untuk melakukan tugas pelayanan panggilan gereja. Karena tujuan Allah memberikan karunia adalah untuk membangun tubuh Kristus dalam hal ini gereja (I Kor 12:4-7; 14:5,12). Ada bermacam-macam karunia yang Allah berikan kepada jemaat, diantaranya:

- Karunia untuk mengungkapkan Firman Allah, yaitu: 1). Rasul (Yunani apostolos, harafiah seorang yang diutus; utusan, penginjil I Kor 12:28; Ef 4:11). 2). Bernubuat (Yunani profeia, Rm 12:6; I Kor 12:10, 28-29; bnd Ef 4:11). 3). Mengajar (Yunani didaskalia, Rm 12:7; I Kor 12:28 dan Ef 4:11)

- Karunia pelayana praktis, yaitu: 1). Iman (Yunani pistis, I Kor 12:9). 2). Karunia untuk menyembuhkan (Yunani kharismata iamaton, I Kor 12:9, 28,30). 3). Mengerjakan Mujizat (Yunani Energemata dunameon, I Kor 12:10, 28), harrafiah "melakukan kekuatan" karunia ini memberikan kesanggupan untuk mempertunjukkan berbagai mujizat lain (Mat 11:20-23; Kis 9:36).

- Karunia Seperasaan. 1). Pelayanan (Yunani antilpseis I Kor 12:8). 2). Pemberi sedekah yang murah hati (Yunani ho metadidous Roma 12:8). 3). Seorang yang menunjukkan kemurahan (Yunani ho eleon Roma 12:8). 4). Jabatan Pelayanan (Yunani diakonia Roma 12:7 bnd Kis 6:1).

- Karunia mengelola. 1). Kepemimpinan (Yunani kuberneseis, I Kor 12:28) ialah karunia dan kekuasaan untuk memimpin yang dimiliki oleh para tua-tua yang memimpin atau memerintah (I Tim 5:7). 2). Siapa yang memberi pimpinan (Yunani ho proistamenos Roma 12:8).

${ }^{24}$ ML, Thompson, Keluarga Sebagai Pusat Pembentukan (Jakarta: BPK Gunung Mulia, 2001),16 
Kedua, keluarga merupakan media gereja untuk menjangkau masyarakat umum, karena keluarga adalah miniatur gereja yang menyebarluaskan dalam masyarakat. Dimana kehadiran keluarga berpengaruh terhadap kesaksian gereja. Morjorie L. Thompson mengatakan:

Jika gereja menghendaki pembentukan keluarga mereka menampakkan kekristenannya secara nyata, gereja bertanggung jawab membantu para keluarga untuk dengan sadar dan terencana menerapkan nilai-nilai kekristenan dirumah, karena peran ini tidak dapat begitu saja digantikan oleh gereja. Pelayanan utama keluarga yang berhimpun (gereja) bagi keluarga yang menyebar (Rumah tangga-rumah tangga Kristen) adalah untuk mengingatkan keluarga akan perannya dan mendukung keluarga dalam menjalan peran utamanya tersebut. Dengan demikian gereja memotivasi keluarga agar dapat dengan bebas melakukan misinya. ${ }^{25}$

Allah sudah memerintah kita untuk menjadi bagian dari masyarakat Kristen. Saya teringat dengan berbagai perayaan dan peringatan serta peristiwa-peristiwa perjanjian khusus dalam Perjanjian Lama, ada yang setiap hari, ada yang setiap minggu atau pada saat tertentu dalam setahun. Sebelumnya Allah berfirman, "kalian adalah umat-Ku dan kalian harus datang kepada-Ku mempersembahkan diri kalian dan beribadah kepada-Ku" (Imamat 23). Seluruh hidup kita ada dibawah kekuasaan Allah dan mentaatinya karena siapa Dia itu dan siapa kita ini. Kita tahu bahwa dengan mentaati Dia kita akan memperoleh kepuasan dalam hidup. ${ }^{26}$

b. Sarana untuk bertumbuh dan melayani

Gereja adalah Tubuh Kristus dan Yesus kepalanya. Keikut sertaan dalam Tubuh Kristus merupakan saran untuk bertumbuh dan melayani. Perjanjian Baru melukiskan gereja sebaggai suatu masyarakat yang disitu segala karunia rohani dipergunakan untuk mendatangkan pujian bagi Allah dan untuk kebaikan semua orang (bnd Roma 12:4-8; I Kor 112:14). Ibadah adalah tempat untuk menggunakan berbagai karunia rohani kita, dengan demikian belajar untuk memberi maupun menerima. Kita tidak akan menjadi orang yang beriman yang bertumbuh dan hidup kecuali apabila kita berhubungan erat dengan saudara-saudara kita dalam Kristus. Kita juga tidak akan mempunyai pelayanan yang berhasil, karena Allah memakai keterlibatan kita dengan sesama orang Kristen untuk mengajar kita bagaimana melayani (bnd Howard Snyder, 518).

\footnotetext{
2001), 141

${ }^{25}$ Marjorie L. Thompson, Keluarga Sebagai Pusat Pertumbuhan (Jakarta: MPH Gunung Mulia,

${ }^{26}$...., Pola Hidup Kristen (Malang: Gandum Mas, 1990),519
} 
c. Sebagai pusat pengajaran dasar-dasar iman Kristen

Gereja merupakan pusat agar mengajar dimana jemaat dapat melajar tentang kebenaran-kebenaran firman Allah. Eli Tanya menjelaskan salah satu fungsi dari pada gereja adalah pengajaran. Selanjutnya ia menjaskan:

Pengajaran. Inilah fungsi gereja yang meliputi Khotbbah, Sekolah Minggu, kelompok-kelompok stusi dan kegiatan-kegiatan paedagogis lainnya. Gerja bertugas untuk mengkomunikasikan dan membagikan warisan kebenaran-kebenaran Kristen kepada umat-Nya dan semua orang di dunia ini. Ia harus menafsirkan kekendak Allah kepada umat-Nya dan kepada dunia. ${ }^{27}$

Lebih lanjut Eli Tanya menjelaskan bahwa pengajaran-pengaran Gereja dapat diberikan melalui berbagai bentuk diantaranya:

1) Ajaran Gereja (instruction). Ini merupakan pembberian infoemasi tentang faktafakta, seperti bahan-bahan Alkitab, sejarah gereja, atau doktrin-doktrin (ajaranajaran) Kristen. Tidaklah cukup bahwa guru Kristen mengajar sampai disini saja dan berhenti. Hal ini harus diikuti dengan arti dari apa yang telah dikomunikasikan kepada muridnya. Gagasan ini dari kata latin instru-ere," yang artinya membangun.

2) Pendidikan gereja. Pengajaran disini melibatkan keseluruhan pribadi murid dalam proses belajar dan meliputi keterampilan, kebiasaan, sikap serta penilaian si murid yang akan dikembangkan. Ini berasal dari latin "educare" artinya membesarkan.

3) Pembinaan Gereja. Dari latin "nutrire" artinya membina dan mengasuh. Pembinaan mirip pendidikan, hanya lebih dasariah meliputi perkembangan, latihan dan asuhan. Dalam jemaat terdapat iklim pembinaan agama yang tujuannya adalah penyerahan diri. ${ }^{28}$

Pada masa Perjanjian Lama kita dapat melihat bagaimana umat berkumpul dalam sinagoge atau rumah ibadat untuk beribadah, berdoa, belajar tentang Taurat. JD. Douglas menjelaskan, tugas utama perkumpulan sinagoge ialah mengajar orang banyak supaya mengerti Hukum Taurat. Pada masa Perjanjian Baru kita melihat dalam kehidupan jemaat mula-mula Kis 2:41-48. Mereka berkumpul bersama-sama belajar kebenaran Firman Allah.

Dengan demikian jelaslah bahwa keluarga (kumpulan orang-orang percaya yang adalah jemaat) mereka membutuhkan gereja sebagai wadah dimana mereka untuk mendapatkan pengajaran iman Kristen karena gereja juga merupakan persekutuan ajar mengajar, dimana antara anggota satu dengan yang lainnya bisa saling belajar, saling membagi dan menerima.

\footnotetext{
${ }^{27}$ Eli Tanya, Gereja PEndidikan Agama Kristen, (Cianjur: STT CIpanas, 1990), hlm. 7

${ }^{28}$ Ibid. $7-8$
} 


\section{Gereja perlu membuat / membentuk departemen / komisi yang khusus menangani Pendidikan Agama Kristen.}

\section{Secara Struktural}

Secara struktural departemen / komisi Pendidikan Agama Kristen bisa berdiri sendiri atau di bawah departemen yang lain. Kalau dibawah departemen komisi PAK merupakan badan pembantu Majelis jemaat gereja setempat yang diangkat, ditetapkan, dikoordinir dan diarahkan oleh Majelis Jemaat

Dengan terbentuknya Departemen / Komisi pendidikan Agama Kristen sangat menunjang kinerja kegiatan pelayanan gereja. Ada beberapa hal positif dengan adanya komisi pendidikan agama Kristen, menurut Eli Tanya:

1. Badan atau komisi PAK berfungsi untuk melaksanakan supervisi dan perencanaan program bagi seluruh jemaat dan mengkoordinasi kegiatan-kegiatan semua pendidikan yang dirancang departemen-departemen dalam jemaat

2. Badan atau komisi Pendidikan Agama Krsiten, tidak menguasai melainkan kerjasama, sambil mengajukan saran-saran dan nasihat-nasihat menurut kebutuhan yang ada

3. Hal mendirikan badan atau komisi Pendidikan Kristen ini memang bukanlah masalah teologis, melainkan kebijaksanaan administrasi - hal bagaiman sebaiknya manajemen program-program pendidikan ungtuk seluruh jemaat

4. Dengan terbentuknya badan atau komisi Pendidikan Agama Kristen, maka program PAK Jemaat dapat dilaksnakan dengan lebih besar, waktu dan finansial, sebab kini departemen-departemen dalam jemaat diatur untuk tidak lagi bekerja sendiri-sendiri melaksnakan aktifitas yang sama dilakukan oleh Departemen lain ( Camp, Retreat, rekreasi dll) atau pelayanan paedagogis jemaat diatur secara menyeluruh, terpadu sebagai sebab kesatuan (keesaan) yang harmonis. ${ }^{29}$

\section{a. Tugas dan Tanggung Jawab Komisi PAK}

1. Bertanggung jawab secara menyeluruh akan pelayanan paedagogis jemaat

2. Membuat program, mengatur dan berkkordinasi melaksnakan pendidikan Kristen di Gereja. Dalam pembutan program menurut Tomatala perlu memperhatikan unsur-unsusr secara hirarki disusun sebagai berikut: 1) Kebutuhan dasar, 2) Misi, 3) Tujuan, 4) Sasaran, 5) Program Kerja kronologis atau berdasarkan urutan waktu, serta 6) Bidang tugas atau proyek kerja. ${ }^{30}$

3. Menentukan, memilih, merekrut tenaga-tenaga pengajar PAK di gereja untuk semua kelompok

4. Mengadakan pelatihan - pelatihan bagi tenaga pengajar

5. Menyediakan, mengadakan perpustakaan dan materi-materi pengajaran dan lain-lain.

\section{Gereja perlu membuat Kurikulum Pendidikan Agama Kristen}

Gereja perlu menyusun kurikulum Pendidikan Agama Kristen dengan memperhatikan ketentuan-ketentuan dalam penyusunan kurikulum

a. Ketentuan dalam pembuatan Kurikulum.

1. Isi kurikulum harus bersifat Alkitabiah dalam arti harus sesuai dan bersumber pada Alkitab

\footnotetext{
${ }^{29}$ Eli Tanya, Gereja Dan PAK (Cipanas, STT Cipanas, 1999), 181

${ }^{30}$ Yakub Tomatala, Kepemimpinan Yang Dinamis ( Malang: Gandum Mas, 1977),168
} 
2. Isi / bahan kurikulum harus harus disesuaikan dengan pertumbuhan dan perkembangan anak didik. Oleh karena setiap kelompok memiliki kebutuhan dan kemampuan yang berbeda anatar kelompok yang satu dengan kelompok yang lain

3. Kurikulum harus sesuai dengan kebutuhan, program denominasi masingmasing gereja

4. Dalam pembuatan kurikulum dapat menggunakan sitem catur wulan, semester atau tahunan.

b. Bentuk Bentuk Kurikulum

1. Kurikulum Berdasarkan Kelompok

Maksud dari pada kurikulum berdasarkan kelompok adalah kurikulum disusun / disesuaikan dengan kelompok-kelompok yang ada dalam gereja. Misalnya, Kurikulum untuk anak Batita, Balita, Kelas Kecil, Tengah dan Besar, Remaja, Pemuda dll. Sebagaimana juga dijelaskan oleh Eli Tanya bahwa kurikiulum harus dapat disesuaikan dengan kebutuhan gereja tertentu (harus luwes sifatnya), kurikulum harus sesuai dengan kebutuhan pengajaran yang diberikan. Misalnya untuk sekolah Munggu atau kelas Katekisasi ${ }^{31}$.

2. Kurikulum Terpadu

Maksud dari kurikulum terpadu adalah kurikulum itu berlaku untuk semua kelompok pelayanan yang ada di Gereja, Misalkan: Tema pembahasan pada bulan itu berbicara tentang dosa, maka semua kelompok baik batita sampai lansia membahas tema yang sama hanya metode yang berbeda.

\section{Gererja Perlu Pengadaan Tenaga PAK}

Disamping membuat / membentuk komisi PAK dan menyususn kurikulum PAK, gereja saat ini perlu menyaipkan tenaga ahli pada bidang PAK. Dengan adanya tenaga ahli pada bidang PAK akan membawa dampak yang sangat baik dalam kinerja pelayanan gereja, menurut Eli Tanya dengan pengangkatan tenaga khusus PAK

1. Akan sangat menolong untuk meringankan tugas-tugas pelayanan Gembala Sidang

2. Mereka dapat membantu dan mengelola, bekerja sama dengan Pendeta, Program PAK yang diintegrasikan ke dalam program menyeluruh dari jemaat.

Pengadaan tenaga ahli dibidang Pendidikan Agama Kristen dapat dilakuakn dengan cara:

1. Mengutus studi lanjut kepada Hamba Tuhan baik pada strata 1 atau 2

2. Bekerjasama dengan Sekolah Theologia untuk mengadakan pelatihan secara berkala dan rutin di Gereja Tentang PAK

\footnotetext{
31 Eli Tanya, Gereja.., 34
} 


\section{Gereja perlu memberdayakan Persekutuan Keluarga}

Gereja mendorong mengupayakan agar tiap-tiap anggota keluarga memiliki jam ibadah / persekutuan anggota keluarga setiap harim untuk itu Gereja perlu:

1. Menyiapkan bentuk liturgi persekutuan keluarga

2. Gereja menyiapkan daftar bacaan Firman Tuhan setiap hari dalam tiap minggu yang dimuat dalam warta jemaat

3. Gereja bisa mengupayakan kerjasama dengan program siaran radio rohani untuk anggota keluarga menjadi kelompok-kelompok pendengar

4. Hamba Tuhan mengadakan kunjungan rutin secara bergiliran dan beribadah bersama keluarga yang dikunjungi.

\section{KESIMPULAN}

Pendidikan Agama Kristen Gereja dan Pendidikan Agama Kristen Keluarga memiliki keterkaitan atau hubungan antara lain: Pertama, secara teologis. Baik gereja maupun keluarga mempunyai mandat untuk mengajar, oleh karena perintah mengajar dalam Mat 28: 19-20 tidak hanya diberikan kepada gereja tetapi juga pada setiap keluarga. Kedua, secara Paedagogis. 1) dari segi pendidik / pengajar baik pendidik di Gereja maupun di Keluarga memiliki persyaratan yang sama menyangkut pengalaman rohani, perlengkapan dsb, 2) Dari segi anak didik, baik pendidikan Agama Kristen di Gereja maupun Pendidikan Agama Kristen di Keluarga adalah setiap pribadi baik itu sebagai anggota jemaat / gereja maupun sebagai anggota keluarga Kristen, 3) Dari segi materi, sama-sama bersumber pada Alkitab. Ketiga, kesamaan dalam tujuan yaitu: 1) mempertemukan pribadi orang berdosa kepada Kristus, 2) Mengubah karakter, 3) Membawa seseorang untuk menjadi saksi Kristus. Keempat, Gereja dan keluarga saling membutuhkan. 1) Gereja membutuhkan keluarga, karena keluarga merupakan miniatur gereja; keluarga sebagai ujung tombak misi gereja. 2) Keluarga membutuhkan gereja, karena: Gereja sebagai wadah bersekutu dengan sesama dalam kelompok yang lebih besar; gereja sebagai sarana untuk bertumbuh dan melayani; gereja sebagai pusat pengajaran dasar-dasar iman kristen.

Mengingat realita-realita dan tanggung jawab gereja sebagai persekutuan proses pembelajaran, tanggung jawab gereja dalam Pendidikan Agama Kristen serta realita adanya realita Pendidikan Agama Kristen Keluarga, keluarga sebagai pusat pendidikan Agama Kristen dan tanggung jawab keluarga dalam Pendidikan agama Kristen, serta realita adanya hubungan antara Pendidikan Agama Kristen Gereja dan Keluarga maka, Gereja perlu membentuk Departemen / komisi Pendidikan Agama Kristen. Dan secara struktural Departemen / Komisi PAK bisa berdiri sendiri atau di bawah Departemen atau komisi yang lain; Gereja perlu membuat kurikulum Pendidikan Agama Kristen. Hal yang 
perlu diperhatikan dalam pembuatan kurikulum adalah kurikulum harus bersifat Alkitabiah dan disesuaikan dengan pertumbuhan dan perkembangan anak didik, oleh karena setiap kelompok memiliki kebutuhan dan kemampuan yang berbeda; Gereja perlu mengadakan pengadaan tenaga Pendidikan Agama Kristen. Hal ini dapat dilakukan dengan mengutus hamba Tuhan mengikuti studi lanjut program S2 PAK; Gereja perlu memberdayakan persekutuan Keluarga, yaitu mendorong, mengupayakan agar anggota jemaat / masingmasing keluarga memiliki jam ibadah keluarga setiap hari. 


\section{DAFTAR PUSTAKA}

Alwi, Hasan,

2001 Kamus Besar Bahasan Indonesia,

Jakarta: Pusat Basaha Departemen Pendidikan Nasional

Ch. Abineno, Jl,

1965 Jemaat, Jakarta: BPK Gunung Mulia

G. Horigahausen, E,

1999 Pendidikan Agama Kristen, Jakarta: BPK Gunung Mulia

Horby, As,

2000 Oxford Advanced Leaner's, Oxford: University Press

Hulmes, L,

1982 Arah Pendidikan Kristen, Batu: YPPII

Laufer, Ruth,

1997 Pedoman Pelayanan Anak, Batu: Dept.Lit YPPII

L. Thompson, M,

2001 Keluarga Sebagai Pusat Pembentukan,

Jakarta: BPK Gunung Mulia

O Gangel, Kenneth,

1998 Membina Pemimpin Pendidikan Kristen, Malang: Gandum Mas

R, Boehlke, Robert,

1997 Sejarah Perkembangan Pemikiran dan

Praktik Pendidikan Agama Kristen, Jakarta: BPK Gunung Mulia

Soediono, Tertius,

1994 Pembimbing PAK (diktatkuliah),

Yogyakarta: Fakultas Agama Kristen UKRIM

Sulaiman, C,

1977 Lokakarya PAK dan Statistik PAK,

Sukabumi: Dirjen Bimas Kristen

S. Sidjabat, B,

1994 Strategi Pendidikan Kristen, Yogyakarta: Yayasan Andi

1987 Pengantar Ketinjauan Historis Filosofis, Bandung: IAT

Tanya, Eli,

1999 Gereja dan Pendidikan Agama Kristen, Cipanas: STT Cipanas

1999 Gereja dan PAK, Cipanas: STT Cipanas

Tomatala, Yakob,

1977 Kepemimpinan Yang Dinamis, Malang: Gandum Mas T. Sisemore, John, 1966 Vital Principle In Religius Education, Nasvile: Broodman Press

Verkuyl, J,

1984 Aku Percaya, Jakarta: BPK Gunung Mulia

1990 Pola Hidup Kristen, Malang: Gandum Mas 